\title{
PHABSIM analysis of a straight trapezoidal reach and a highly sinuous reach in a low-order agricultural stream in the midwest
}

\author{
Mark R. Tompkins ${ }^{(1)}$, and Edwin Herricks ${ }^{(2)}$ \\ Corresponding author : Mark R. Tompkins, mtompkin@ch2m.com
}

\begin{abstract}
The PHABSIM model was applied to adjacent straight trapezoidal and highly sinuous reaches in a third order agricultural stream in East-Central Illinois. A 30year flow record was used to generate weighted usable area (WUA) estimates for six warmwater fish species for each reach. Supplementing PHABSIM analysis, detailed surveys provided planametric maps of each reach, and regular fish sampling both supported the selection of species modeled with PHABSIM and provided data for PHABSIM evaluation. Analysis of the 30-year WUA estimates supported the development of metrics for fish community analysis, and the analysis of selected fish species populations in each reach. Six monthly fish collections in each reach provided a basis for and a detailed description of the fish communities in each reach. Metrics developed for four of the six species modeled were positively related to the relative differences in numbers of fish present between the two reaches.
\end{abstract}

Key words. - PHABSIM, agricultural drainage streams, channel maintenance, fish community analysis metrics, stream channel geomorphology change, stream restoration

\section{INTRODUCTION}

The Physical HABitat SIMulation Model (PHABSIM) has been used extensively in the United States and Canada to investigate changes in stream physical habitat caused by changes in hydrologic parameters (Reiser et al. 1989; Armour and Taylor 1991). Essentially, PHABSIM is a vehicle for presenting biological information in a format suitable for entry into the water resources planning pro- cess (Gore and Nestler 1988). Despite its widespread use, especially in Western U.S. streams, PHABSIM has been criticized. The majority of the critiques have focused on a lack of correspondence between WUA and actual density or biomass of fish present (Mathur et al. 1985; Bowlby and Roff 1986; Scott and Shrivell 1987).

Although PHABSIM has been criticized, it remains as one of the most commonly used methods of relating flow and fisheries potential. Further,

(1)1668 Capistrano Avenue, Berkeley, CA 94707

(2) 3230b NCEL, 205 North Matthews, Urbana, IL 61801 
PHABSIM is a useful tool for investigating a number of issues in stream habitat management. For example, simple observations suggest that habitat quality should differ between straight and meandering stream reaches. It is possible to map channels, to measure flow conditions, and to sample fish to make comparisons, but such comparisons provide only a snapshot of conditions and only a limited basis for extrapolation to different flow conditions. PHABSIM provides a means of simulating stream habitat dynamics and provides the basis for extrapolating comparisons of available habitat in stream reaches with varying morphology over time.

In this paper we provide a comparative analysis of two stream reaches with different habitat that were subject to the same physical and water quality conditions. Because the reaches were adjacent, similar biotic potential exists for each reach. Our overall objective in conducting this re- search was to use PHABSIM as an estimator of habitat, and site specific fish community information to support the development of alternative management strategies for streams in landscapes dominated by agriculture and specifically managed for agricultural drainage.

\section{METHODS}

\section{Site Selection}

We selected two reaches of the Embarras River, located in Champaign County, Illinois, for this study (Figure 1). Permit requirements in 1997 prohibited change in a meandering reach while downstream areas were modified to produce a trapezoidal channel with some removal of streambed substrate and gradient alteration. The Embarras River originates in agricultural land just south of the University of Illinois campus and

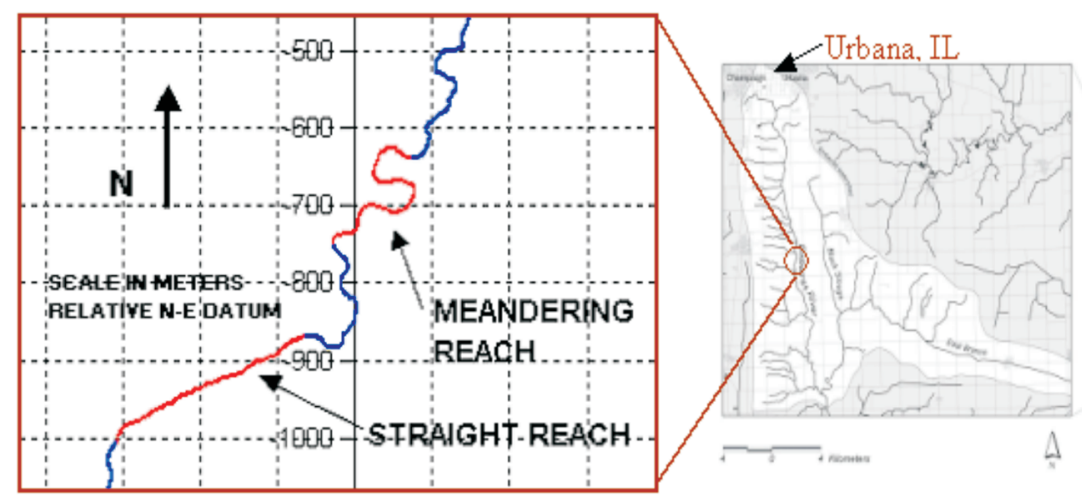

Fig. 1. - Location of study reaches. 
flows south approximately 190 miles before its confluence with the Wabash River. Its watershed is between eighty and ninety percent agricultural, much of which has been dredged and drained of wetlands (Durham 1997). Water quality in the Embarras River has been classified as minimally impaired based on water quality indices (Durham 1997). Figures 2 and 3 are photographs of each study reach paired with topographic maps of the highly sinuous reach and the straight trapezoidal reach, respectively.

\section{Fisheries Collections}

Fisheries information for the Embarras River are available from studies conducted as early as 1890 . We used the historical fisheries data to develop a context for this analysis by establishing species presence and
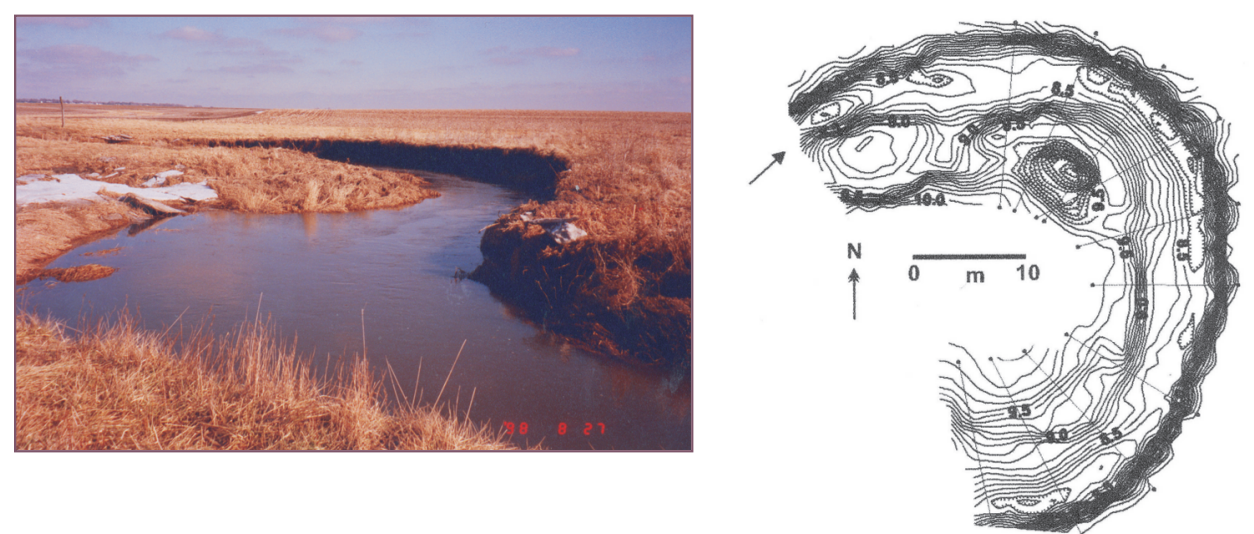

Fig. 2. - Photo of highly sinuous reach looking upstream and topographic reach map.
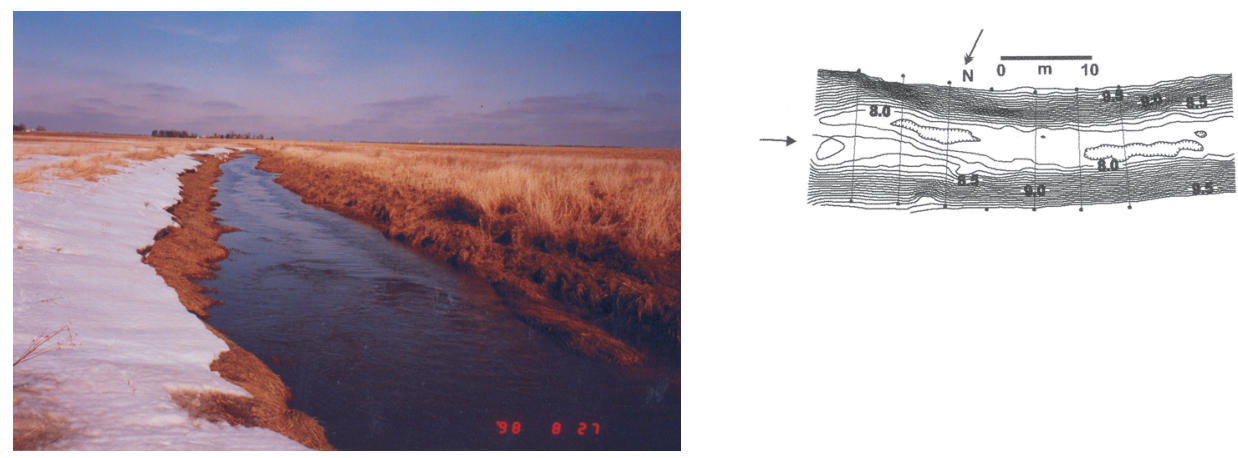

Fig. 3. - Photo of straight trapezoidal reach looking upstream and topographic reach map. 
abundance through time at locations similar to the study site. Supplementing this historical information, regular fish sampling was conducted in the study reaches. Monthly samples were collected from July 1997 to February 1998. Sampling for fish followed standard procedures. First, block nets were placed at the upstream and downstream ends of each site. One person operated a Coffelt Mark-10 backpack shocker while one or two other people netted the stunned fish. The sampling started at the downstream end of the reach and moved to the upstream net. Direction was reversed and sampling continued downstream to the downstream block net where stunned fish were retrieved as the downstream net was removed and examined. Net locations were fixed for all sampling, and sampling time and effort were monitored to allow assessment of sampling effort consistency between samples. Collected fish were identified and measured. Weight and length was recorded for the first twenty-five individuals of each species. When positive identification was not possible in the field, specimens were stunned and preserved in formalin. The preserved specimens were returned to the lab for positive identification. Fish collection data was tabulated by date and site. For each of the species analyzed in this research, an average length and average weight was calculated. Each average value includes all individuals collected during each of the six monthly samples. The total number of each species collected at each site was summarized, including determination of variability observed in collections.

\section{Embarras River Fisheries Background}

The fish assemblages of the Embarras River have been studied in some detail over the past ninety years (Forbes and Richardson 1908; Smith 1968; Ettinger 1989). In a recent study of aquatic habitat in drainage systems (TerHaar and Herricks 1989), the Embarras was described as a river with a diverse fish fauna. Forty-eight species had been collected in the Embarras River system at the time of the study by TerHaar and Herricks. A review of historical fisheries data indicated that an overall increase in species richness had occurred in the Embarras River.

\section{PHABSIM Model Development}

\section{Input Data Collection}

We selected four cross-sections in the highly sinuous reach and three cross sections in the straight trapezoidal reach (Figure 4) to describe major habitat conditions in the PHABSIM models. We surveyed each cross section according to the guidelines provided by Bovee (1996). We supplemented the information in the cross section surveys with a comprehensive geomorphic assessment of each study reach. The four crosssections in the highly sinuous reach represent three major types of habi- 


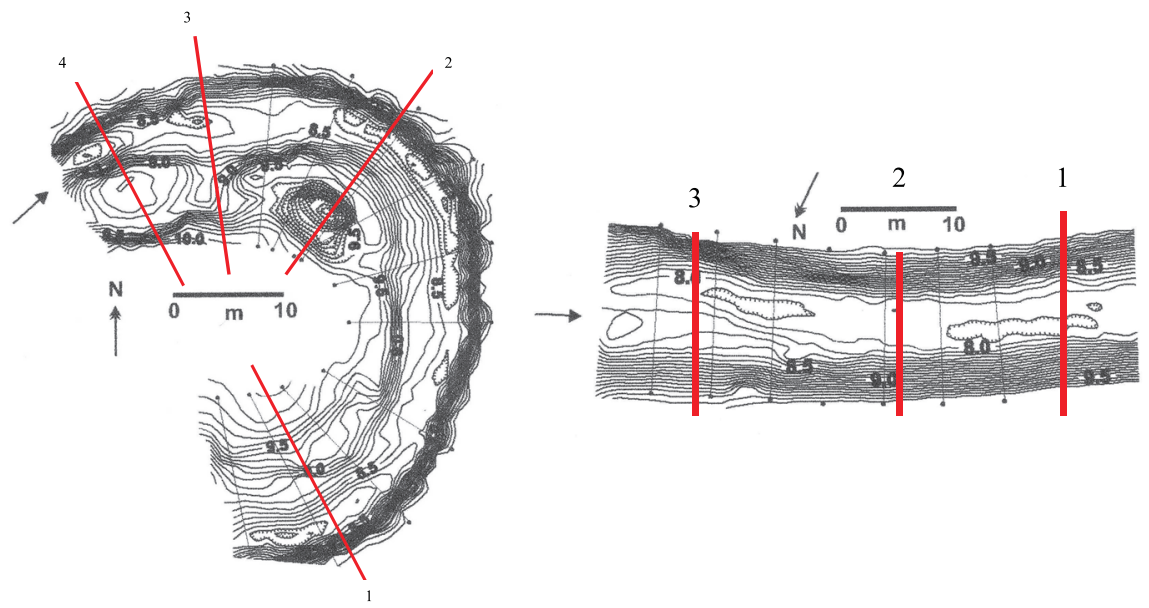

Fig. 4. - Approximate locations of cross sections in the highly sinuous and straight trapezoidal PHABSIM models of the Embarras River.

tat, the fourth providing a hydraulic control for model calibration. Cross section \#1 was a local hydraulic control. Cross section \#2 represented the "run" type habitat. We defined a run in the Embarras River as a smoothly flowing area of moderate depth and uniform flow characteristics located between pools and riffles. Cross-section \#3 represented the "riffle" type habitat. We defined a riffle in the Embarras River as a shallow area of relatively high velocity and mixed gravel-cobble substrate (Allan, 1995). Cross section \#4 represented a "pool" type habitat. We defined a pool in the Embarras River as a deeper area of slower velocity and finer substrate (Allan, 1995). The physical habitat in the straight trapezoidal reach was homogeneous. We selected three cross sections in this reach. Cross section \#1 acted as a local hydraulic control. The other two cross-sections provided reach definition as a trapezoidal channel with a uniform bottom width, and established reach gradient.

\section{Water Surface Profile and Velocity Models}

We calibrated the Water Surface Profile (WSP) model and the IFG4 velocity model for both study reaches using the methods outlined by Bovee (1982). We used two sets of measured water surface elevations and velocities collected at two different discharge levels in each calibration. We measured the water surface elevation at each cross-section using an auto level and stadia rod. We also measured flow velocity at each crosssection and computed discharge using the velocity and cross-sectional data. We used the calibrated WSP 
models to model water surface elevations for the expected range of flows at each site. We used the calibrated IFG4 model to model velocities for the expected range of flows at each site.

\section{Hydrology}

We performed a correlation analysis (Tompkins 1998) with approximately five months of flow data measured at the study site and the same five months of flow data from the USGS gage on the Embarras River at Camargo, Illinois. We used the results of the correlation analysis to generate an equation for flow at the study site as a function of flow at the Camargo gage. We generated a $30-$ year synthetic flow record for the study sites using this equation and the Camargo gage record for the prior 30 years.

\section{Habitat Modeling}

We used the HABTAE habitat model in PHABSIM for all modeling exercises. We selected species for use in the PHABSIM modeling based on several factors. We made an initial analysis of the fish collection data to determine which species were present in at least 50 percent of the samples. We then examined this set of species for species that showed significant differences in numbers and/ or biomass between the highly sinuous and straight trapezoidal sites. This analysis provided a pool of species filling a number of niches, or guilds. We made final selections to provide a set of species that was as representative of as many of these guilds as possible so that the modeling exercises would cover fish that use a range of physical habitat types.

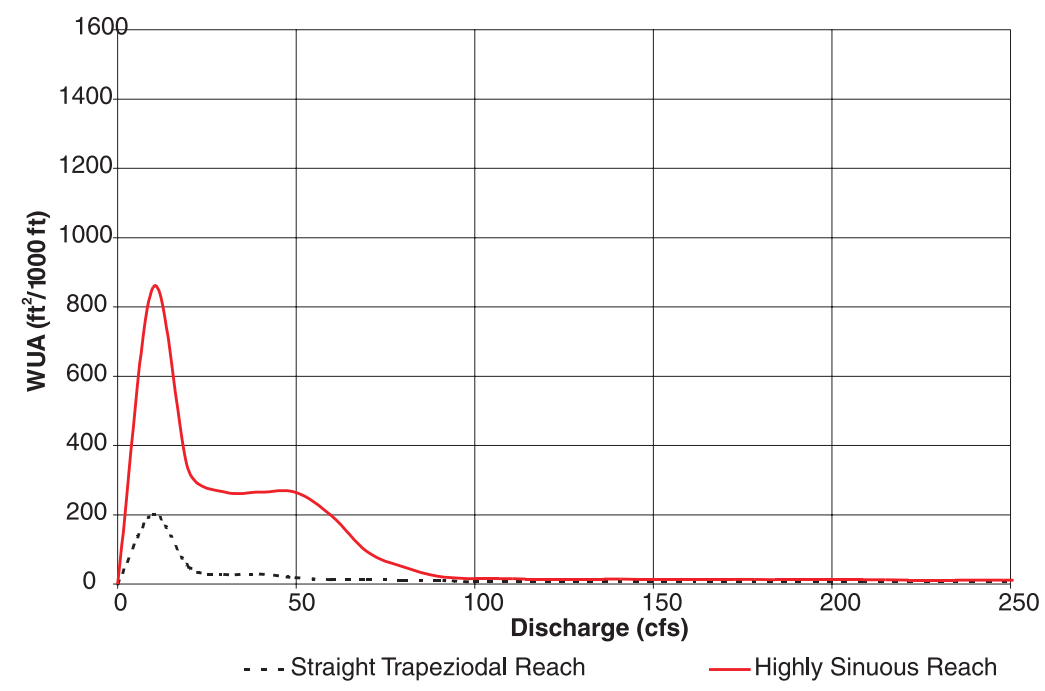

Fig. 5. - Juvenile Bluntnose Minnow HRC showing weighted usable area (WUA) versus discharge in the straight trapezoidal reach and the highly sinuous reach. 


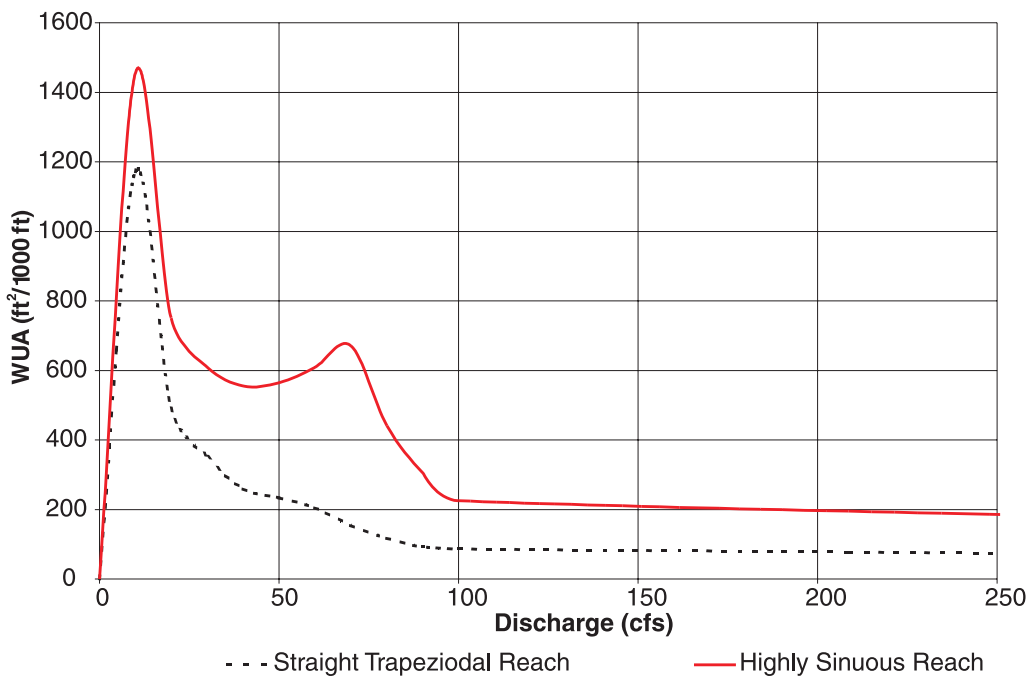

Fig. 6. - Adult Bluntnose Minnow HRC showing weighted usable area (WUA) versus discharge in the straight trapezoidal reach and the highly sinuous reach. Note the second peak WUA that occurs with a discharge of approximately $70 \mathrm{cfs}$ in the highly sinuous reach. This occurs as riparian habitat becomes inundated with increasing discharge.

From this final set of species, we made final selections to incorporate the species having the best available habitat suitability information for PHABSIM modeling. We selected six species for habitat modeling. Table 1 lists the species used in our analysis and describes the habitat suitability curves used for each species. We re- ferred to the output of the habitat modeling procedure in this work as a "habitat response curve," or HRC. The HRC gives a relationship between discharge and weighted usable area for each species and lifestage. Figures 5 and 6 show example HRCs for the juvenile and adult Bluntnose Minnow, respectively. We

Table 1. - Fish species used in habitat modeling and summary of habitat suitability curve availability.

\begin{tabular}{|c|c|c|c|}
\hline Common Name & Scientific Name & Curves Available & Type \\
\hline Bluntnose Minnow & Pimephales promelas & Juvenile, Adult & East Central Illinois \\
\hline Central Stoneroller & Campostoma anomalum & Adult & General \\
\hline Creek Chub & Semotilus atromaculatus & Juvenile, Adult & East Central Illinois \\
\hline Greenside Darter & Etheostoma blennioides & Juvenile, Adult & General \\
\hline Longear Sunfish & Lepomis megalotis & Juvenile, Adult & East Central Illinois \\
\hline Striped Shiner & Luxilus chrysocephalus & Juvenile, Adult & East Central Illinois \\
\hline
\end{tabular}


used the HRCs to generate a 30-year record of WUA for each species and lifestage.

\section{Data Analysis}

We analyzed the historical WUA data sets for each species using a variety of techniques. First, we calculated basic statistics for the historical WUA data for each lifestage of each species modeled. Next, we performed a difference analysis (Tompkins 1998) on the historical record of WUA. We compared daily WUA values for the highly sinuous reach with daily WUA values for the straight trapezoidal reach using the following equation.

$D_{t}=\left\{\begin{array}{c}\left.1-\left(\frac{W U A_{s t_{t}}}{W U A_{h s_{t}}}\right)\right) \text { if } W \cup A_{h s_{t}} \geq W U A_{s t_{t}} \\ -1\left(1-\left(\frac{W U A_{h s_{t}}}{W U A_{s t_{t}}}\right)\right)\end{array}\right\}$ if $W \cup A_{h s_{t}}<W U A_{s t_{t}}$

Where :

$D_{t}=$ Degree of difference between weighted usable area in the straight trapezoidal reach and weighted usable area in the highly sinuous reach for a given species and lifestage at time " $t$ "

$W U A_{\text {stt }}=$ Weighted usable area in the straight trapezoidal reach for a given species and lifestage at time " $t$ "

$W U A_{h s t}=$ Weighted usable area in the highly sinuous reach for a given species and lifestage at time " $t$ "

The above equation expresses the "degree of difference" between the two values as a number between negative one and one. A negative degree of difference indicates that the straight trapezoidal reach WUA value was greater than the highly sinuous reach WUA, and a positive degree of difference indicates that the highly sinuous reach WUA value was greater than the straight trapezoidal reach WUA. We calculated basic statistics for the difference analysis data set as well.

\section{RESULTS AND DISCUSSION}

Results are presented below for each of the six species analyzed in this study.

\section{Weighted Useable Area Results}

\section{Bluntnose Minnow}

Summary statistics for the WUA data set for this species are presented in Table 2.

The ratios between the straight trapezoidal reach WUA and the highly sinuous reach WUA provide a metric for comparison. This analysis predicted that on average the juvenile WUA for the straight trapezoidal reach was only 15 percent of the WUA in the highly sinuous reach. Adult WUA is also smaller in the straight trapezoidal reach, on average it is 49 percent of the WUA in the highly sinuous reach. The difference analysis provides perhaps the most useful information. The statistics for this analysis are presented in Table 3. 
Table 2. - Summary statistics for Bluntnose Minnow daily WUA values.

\begin{tabular}{|c|c|c|c|c|c|c|c|c|}
\hline Reach & $\begin{array}{c}\text { Juvenile } \\
\text { Mean } \\
\text { WUA }^{*}\end{array}$ & $\begin{array}{c}\text { Adult } \\
\text { Mean } \\
\text { WUA }^{*}\end{array}$ & $\begin{array}{c}\text { Juvenile } \\
\text { Standard } \\
\text { Devia- } \\
\text { tion }\end{array}$ & $\begin{array}{c}\text { Adult } \\
\text { Standard } \\
\text { Devia- } \\
\text { tion* }\end{array}$ & $\begin{array}{c}\text { Juvenile } \\
\text { Maximum } \\
\text { WUA }^{*}\end{array}$ & $\begin{array}{c}\text { Adult } \\
\text { Maximum } \\
\text { WUA }^{*}\end{array}$ & $\begin{array}{c}\text { Juvenile } \\
\text { Minimum } \\
\text { WUA }^{*}\end{array}$ & $\begin{array}{c}\text { Adult Mi- } \\
\text { nimum } \\
\text { WUA }^{*}\end{array}$ \\
\hline $\begin{array}{c}\text { Straight } \\
\text { Trapezoidal }\end{array}$ & 26.9 & 256.4 & 34.3 & 224.2 & 178.2 & 1078.5 & 5.7 & 54 \\
\hline $\begin{array}{c}\text { Highly } \\
\text { Sinuous }\end{array}$ & 179.1 & 518.6 & 175.7 & 273 & 781.6 & 1354.1 & 3.8 & 134.7 \\
\hline $\begin{array}{c}\text { Ratio } \\
\text { S:H) }\end{array}$ & 0.15 & 0.49 & 0.20 & 0.82 & 0.22 & 0.80 & 1.50 & 0.40 \\
\hline
\end{tabular}

* WUA values for the straight trapezoidal reaches and the highly sinuous reach presented in units of $\mathrm{ft}^{2} / 1000 \mathrm{ft}$

Table 3. - Summary statistics for Bluntnose Minnow difference analysis.

\begin{tabular}{|l|c|c|c|c|}
\hline Lifestage & $\begin{array}{c}\text { Mean } \\
\text { Difference }\end{array}$ & $\begin{array}{c}\text { Standard } \\
\text { Deviation }\end{array}$ & $\begin{array}{c}\text { Maximum } \\
\text { Difference }\end{array}$ & $\begin{array}{c}\text { Minimum } \\
\text { Difference }\end{array}$ \\
\hline Juvenile & 0.72 & 0.26 & 0.93 & -0.34 \\
\hline Adult & 0.56 & 0.15 & 0.77 & 0.21 \\
\hline
\end{tabular}

The values in Table 3 require some explanation. Recall that the goal of the difference analysis was to compare each daily WUA value from the highly sinuous reach to each daily WUA value from the straight trapezoidal reach. This analysis returned a fraction indicating how much more WUA was present in one reach or the other for each day in the period of record. A negative value means that on average there is greater daily WUA in the straight trapezoidal reach and a positive value means that on average there is greater daily WUA in the highly sinuous reach. An explanation using the statistics for the juvenile Bluntnose Minnow presented in Table 3 follows.

The mean difference of 0.72 for the juvenile Bluntnose Minnow (column 1, row 1 in Table 3) means that on average, the daily WUA in the highly sinu- ous reach is 72 percent better than in the straight trapezoidal reach, with a standard deviation of 26 percent. At the extremes, daily WUA is 93 percent better in the highly sinuous reach and 34 percent better in the straight trapezoidal reach (indicated by a -34 percent minimum difference). The mean difference could be used as a metric for the comparison of stream alteration techniques for different species. As will become apparent in the discussion of results for the other species, this mean difference value will vary between species and could therefore be used to assign levels of potential sensitivity to channel alteration for different species. Figure 7 includes a plot of the single year difference analyses for juveniles for 1988 and 1990 as well as the daily WUA values for juvenile Bluntnose Minnow in the straight trapezoidal 


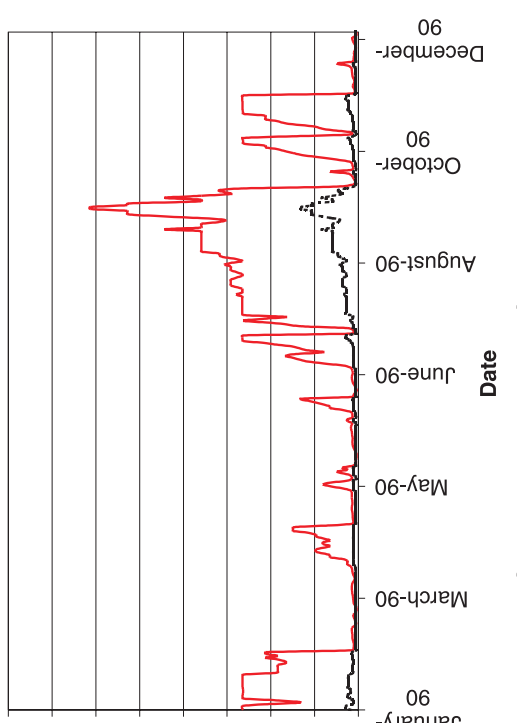

১: \& \& \& \& (H $000 \mathrm{~L} / z^{\text {H) }} \forall \cap M$

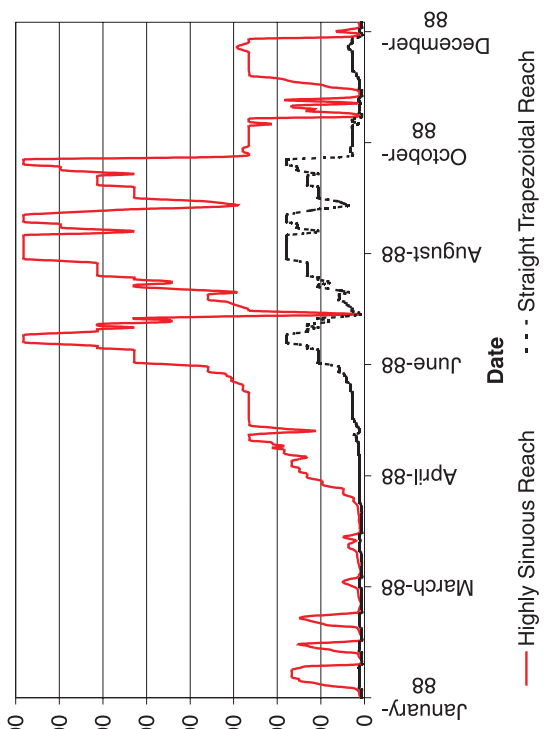

\& \& \& 8 \& \& \& (H $000 \mathrm{~L} / z^{\text {H) }} \forall \cap M$

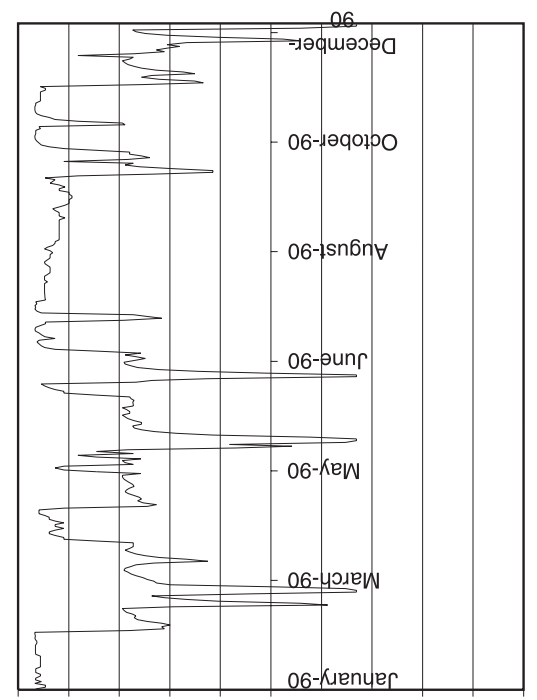

○.

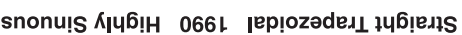

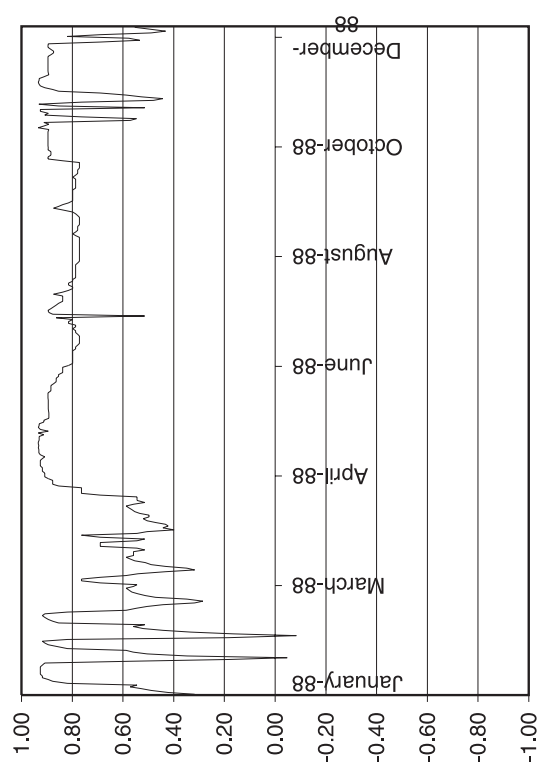

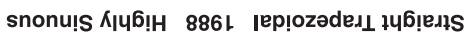

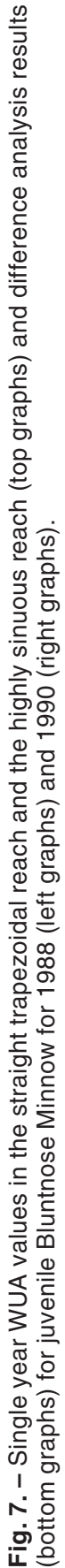


and highly sinuous reaches in 1988 and 1990 . Figure 8 presents the same information for the adult lifestage. The first year, 1988, was a relatively dry year, and the second, 1990, was a relatively wet year. The differences in available habitat are noticeable between the two years, with a smaller proportion of higher WUA values in the highly sinuous reach in 1988. It is expected that this method of analysis could also be implemented in investigations of the sensitivity of the physical habitat in different stream channel morphologies to changing flow regimes.

\section{Central Stoneroller}

Summary statistics for this species are presented in Table 4.

Using the ratios between the straight trapezoidal reach WUA and the highly sinuous reach WUA as a metric for comparison, this analysis predicted that on average the WUA in the straight trapezoidal reach was ap- proximately equal to the WUA in a natural reach for the adult Central Stoneroller. The standard deviation is significantly higher in the straight trapezoidal reach and may be indicative of less suitable, highly fluctuating physical habitat conditions. The statistics for the difference analysis are presented in Table 5. On average, the daily WUA values are 15 percent higher in the highly sinuous reach for the adult Central Stoneroller.

\section{Creek Chub}

Summary statistics for this species are presented in Table 6.

The ratios between the mean WUA in the straight trapezoidal reach and the mean WUA in the highly sinuous reach show that on average there is greater WUA in the highly sinuous reach for both life stages. The statistics for the difference analysis are presented in Table 7. On average, the daily WUA values are 54 and 77 percent higher in the highly sinuous

Table 4. - Summary statistics for Central Stoneroller daily WUA values.

\begin{tabular}{|l|c|c|c|c|}
\hline Reach & $\begin{array}{c}\text { Adult Mean } \\
\text { WUA* }\end{array}$ & $\begin{array}{c}\text { Adult Standard } \\
\text { Deviation* }\end{array}$ & $\begin{array}{c}\text { Adult Maximum } \\
\text { WUA }^{*}\end{array}$ & $\begin{array}{c}\text { Adult Minimum } \\
\text { WUA }^{*}\end{array}$ \\
\hline Straight Trapezoidal & 2182.8 & 1959.7 & 9122.6 & 133.2 \\
\hline Highly Sinuous & 2161.9 & 696.4 & 3683.8 & 1112.2 \\
\hline Ratio (S:N) & 1.00 & 2.81 & 2.48 & 0.12 \\
\hline
\end{tabular}

* WUA values for the straight trapezoidal reaches and the highly sinuous reach presented in units of $\mathrm{ft}^{2} / 1000 \mathrm{ft}$

Table 5. - Summary statistics for Central Stoneroller difference analysis

\begin{tabular}{|l|c|c|c|c|}
\hline Lifestage & Mean Difference & Standard Deviation & Maximum Difference & Minimum Difference \\
\hline Adult & 0.15 & 0.49 & 0.91 & -0.61 \\
\hline
\end{tabular}




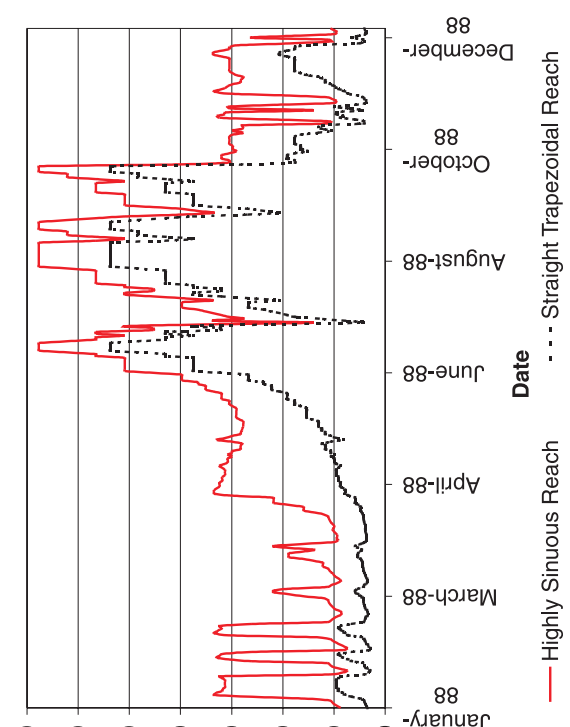

원 웅 \& (H $000 \mathrm{~L} / \mathrm{Z}^{\text {H) }} \forall \cap \mathrm{M}$

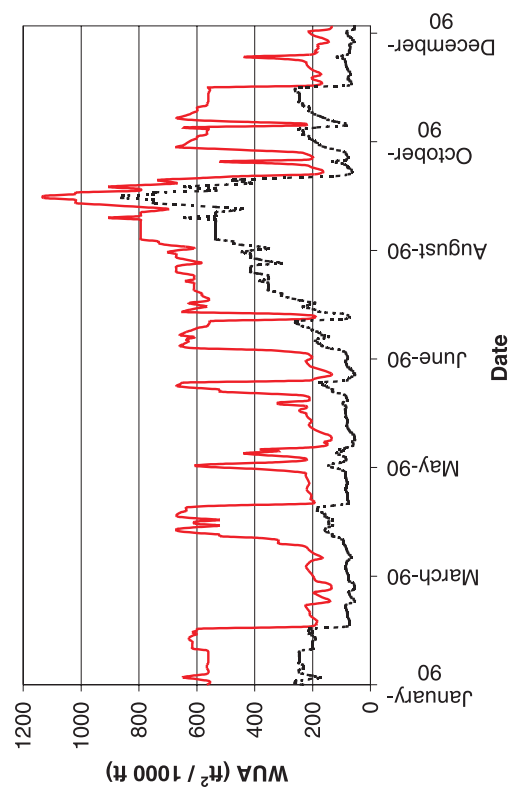

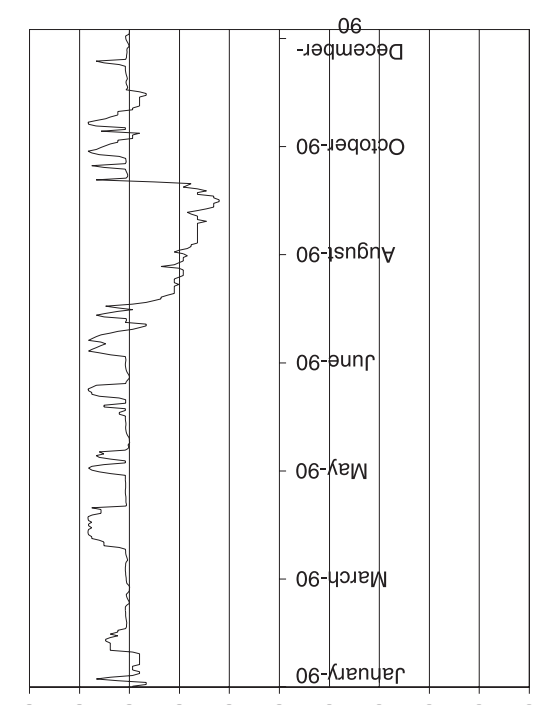

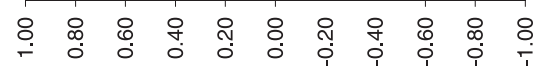
snonu!s Кㄴ6!

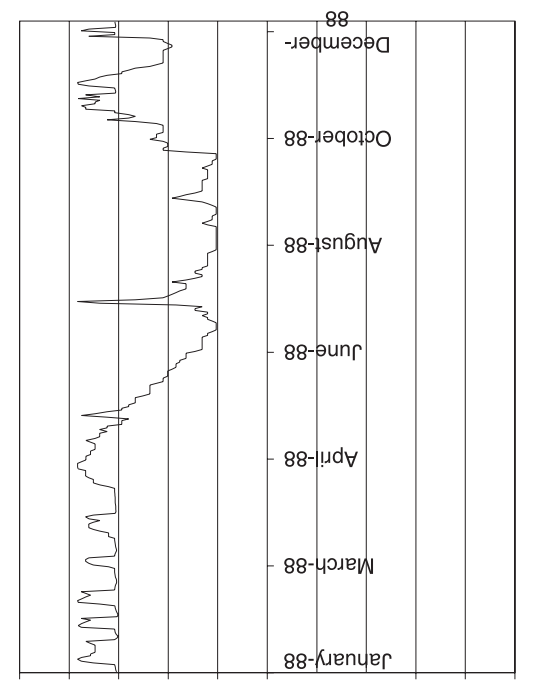

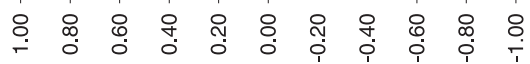

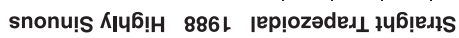

동

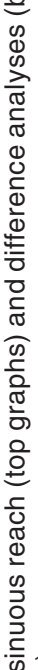

के 층휴 б 氜 응 당 요

든

đั

중 (ิ)

응 동

시 중

흐

$\stackrel{\frac{\pi}{2}+\frac{1}{0}}{\frac{1}{2}}$

응

니

음

흔

.

क

을

$>0$

ऽ

引

ส $\frac{5}{0}$

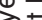

음 휴 ज 흐

1. क

ㅎํㄴ 흔 
reach for the juvenile and adult Creek Chub, respectively.

\section{Greenside Darter}

Summary statistics for this species are presented in Table 8.

The ratios between the mean WUA in the straight trapezoidal reach and the mean WUA in the highly sinuous reach show that on average there is greater WUA in the straight trape- zoidal reach for both life stages. The statistics for the difference analysis are presented in Table 9. On average, the daily WUA values are approximately 20 percent higher in the straight trapezoidal reach for both lifestages of the Greenside Darter.

\section{Longear Sunfish}

Summary statistics for this species are presented in Table 10.

Table 6. - Summary statistics for Creek Chub daily WUA values

\begin{tabular}{|c|c|c|c|c|c|c|c|c|}
\hline Reach & $\begin{array}{c}\text { Juvenile } \\
\text { Mean } \\
\text { WUA }^{*}\end{array}$ & $\begin{array}{c}\text { Adult } \\
\text { Mean } \\
\text { WUA }^{*}\end{array}$ & $\begin{array}{c}\text { Juvenile } \\
\text { Standard } \\
\text { Deviation* }\end{array}$ & $\begin{array}{c}\text { Adult } \\
\text { Standard } \\
\text { Deviation* }\end{array}$ & $\begin{array}{c}\text { Juvenile } \\
\text { Maximum } \\
\text { WUA }^{*}\end{array}$ & $\begin{array}{c}\text { Adult } \\
\text { Maximum } \\
\text { WUA }^{*}\end{array}$ & $\begin{array}{c}\text { Juvenile } \\
\text { Minimum } \\
\text { WUA }^{*}\end{array}$ & $\begin{array}{c}\text { Adult } \\
\text { Minimum } \\
\text { WUA* }^{*}\end{array}$ \\
\hline $\begin{array}{c}\text { Straight } \\
\text { Trapezoidal }\end{array}$ & 105.7 & 26.5 & 89.9 & 45.4 & 492.9 & 249.1 & 30.8 & 2.6 \\
\hline $\begin{array}{c}\text { Highly } \\
\text { Sinuous }\end{array}$ & 265.5 & 87.1 & 157.0 & 72.6 & 510.0 & 384.6 & 52 & 5.7 \\
\hline $\begin{array}{c}\text { Ratio } \\
(\mathrm{S}: \mathrm{H})\end{array}$ & 0.40 & 0.30 & 0.57 & 0.63 & 0.97 & 0.65 & 0.59 & 0.45 \\
\hline
\end{tabular}

* WUA values for the straight trapezoidal reaches and the highly sinuous reach presented in units of $\mathrm{ft}^{2} / 1000 \mathrm{ft}$

Table 7. - Summary statistics for Creek Chub difference analysis

\begin{tabular}{|c|c|c|c|c|}
\hline Lifestage & Mean Difference & Standard Deviation & Maximum Difference & Minimum Difference \\
\hline Juvenile & 0.54 & 0.21 & 0.82 & 0.03 \\
\hline Adult & 0.77 & 0.11 & 0.85 & 0.35 \\
\hline
\end{tabular}

Table 8. - Summary statistics for Greenside Darter daily WUA values

\begin{tabular}{|c|c|c|c|c|c|c|c|c|}
\hline Reach & $\begin{array}{c}\text { Juv } \\
\text { Mean } \\
\text { WUA }^{*}\end{array}$ & $\begin{array}{c}\text { Adult } \\
\text { Mean } \\
\text { WUA }^{*}\end{array}$ & $\begin{array}{c}\text { Juv } \\
\text { STD }^{*}\end{array}$ & $\begin{array}{c}\text { Adult } \\
\text { STD }^{*}\end{array}$ & $\begin{array}{c}\text { Juv } \\
\text { MAX } \\
\text { WUA }^{*}\end{array}$ & $\begin{array}{c}\text { Adult } \\
\text { MAX } \\
\text { WUA }^{*}\end{array}$ & $\begin{array}{c}\text { Juv } \\
\text { MIN } \\
\text { WUA }^{*}\end{array}$ & $\begin{array}{c}\text { Adult } \\
\text { MIN } \\
\text { WUA }^{*}\end{array}$ \\
\hline $\begin{array}{c}\text { Straight } \\
\text { Trapezoidal }\end{array}$ & 14446 & 18265 & 5625 & 3725 & 20907 & 22150 & 5581 & 9153 \\
\hline $\begin{array}{c}\text { Highly } \\
\text { Sinuous }\end{array}$ & 10338 & 13408 & 1475 & 2561 & 12410 & 15977 & 7899 & 6392 \\
\hline $\begin{array}{c}\text { Ratio } \\
\text { (S:H) }\end{array}$ & 1.40 & 1.36 & 3.81 & 1.45 & 1.68 & 1.39 & 0.70 & 1.43 \\
\hline
\end{tabular}

\footnotetext{
* WUA values for the straight trapezoidal reaches and the highly sinuous reach presented in units of $\mathrm{ft}^{2} / 1000 \mathrm{ft}$
} 
The ratios between the mean WUA in the straight trapezoidal reach and the mean WUA in the highly sinuous reach show that on average there is greater WUA in the straight trapezoidal reach for the juvenile lifestage. However, for the adult Longear Sunfish, WUA values are significantly higher in the highly sinuous reach (81 percent). The statistics for the difference analysis are presented in Table 11. The results of the difference analysis show that the daily WUA values for both lifestages of this species are higher in the highly sinuous reach. For the adult Longear Sunfish, the WUA value is on average 78 percent higher in the highly sinu- ous reach, and at no time is the value higher in the straight trapezoidal reach.

\section{Striped Shiner}

Summary statistics for this species are presented in Table 12.

The ratios between the mean WUA in the straight trapezoidal reach and the mean WUA in the highly sinuous reach show that on average there is greater WUA in the highly sinuous reach for the adult Striped Shiner. For the juveniles, WUA values are approximately equal on average. The statistics for the difference analysis are presented in Table 13. On aver-

Table 9. - Summary statistics for Greenside Darter difference analysis

\begin{tabular}{|c|c|c|c|c|}
\hline Lifestage & Mean Difference & Standard Deviation & Maximum Difference & Minimum Difference \\
\hline Juvenile & -0.20 & 0.28 & 0.53 & -0.44 \\
\hline Adult & -0.26 & 0.14 & 0.34 & -0.34 \\
\hline
\end{tabular}

Table 10. - Summary statistics for Longear Sunfish daily WUA values

\begin{tabular}{|c|c|c|c|c|c|c|c|c|}
\hline Reach & $\begin{array}{c}\text { Juv } \\
\text { Mean } \\
\text { WUA }^{*}\end{array}$ & $\begin{array}{c}\text { Adult } \\
\text { Mean } \\
\text { WUA }^{*}\end{array}$ & $\begin{array}{c}\text { Juv } \\
\text { STD }^{*}\end{array}$ & $\begin{array}{c}\text { Adult } \\
\text { STD }^{*}\end{array}$ & $\begin{array}{c}\text { Juv } \\
\text { MAX } \\
\text { WUA }^{*}\end{array}$ & $\begin{array}{c}\text { Adult } \\
\text { MAX } \\
\text { WUA }^{*}\end{array}$ & $\begin{array}{c}\text { Juv MIN } \\
\text { WUA }\end{array}$ & $\begin{array}{c}\text { Adult } \\
\text { MIN } \\
\text { WUA }^{*}\end{array}$ \\
\hline $\begin{array}{c}\text { Straight } \\
\text { Trapezoidal }\end{array}$ & 204 & 19 & 206 & 27 & 706 & 148 & 49 & 2 \\
\hline $\begin{array}{c}\text { Highly } \\
\text { sinuous }\end{array}$ & 177 & 99 & 68 & 118 & 368 & 544 & 86 & 6 \\
\hline $\begin{array}{c}\text { Ratio } \\
\text { (S:H) }\end{array}$ & 1.15 & 0.19 & 3.04 & 0.23 & 1.92 & 0.27 & 0.57 & 0.32 \\
\hline
\end{tabular}

* WUA values for the straight trapezoidal reaches and the highly sinuous reach presented in units of $\mathrm{ft}^{2} / 1000 \mathrm{ft}$

Table 11. - Summary statistics for Longear Sunfish difference analysis

\begin{tabular}{|c|c|c|c|c|}
\hline Lifestage & Mean Difference & Standard Deviation & Maximum Difference & Minimum Difference \\
\hline Juvenile & 0.15 & 0.50 & 0.69 & -0.57 \\
\hline Adult & 0.78 & 0.06 & 0.88 & 0.67 \\
\hline
\end{tabular}


age, the daily WUA values are 17 and 68 percent higher in the highly sinuous reach for the juvenile and adult Striped Shiner, respectively.

\section{Historical Mean Habitat Difference (HMHD)}

The mean values of the difference analysis data sets provide a metric for the analysis of fish populations in streams under different agricultural management practices. When computed for a significantly long period of time, the value provides a historical representation of the physical habitat available to a given species in a stream reach. This historical metric allows comparison between representative stream reaches with a single numeric value that takes into consideration the fact that fish populations develop over long periods of time in a given stream reach. Here, a positive HMHD means historical habitat conditions were better in the highly sinuous reach, and a negative value means that historical habitat conditions were better in the straight trapezoidal reach. Table 14 contains HMHD values for the adult lifestage of each species modeled, along with the results of the fish collection data analysis in both the highly sinuous reach and the straight trapezoidal reach.

The results presented in Table 14 facilitate a more detailed assessment of the physical habitat modeling results. The bold numbers in the second and fifth columns are of particular interest. In the second column, the HMHD values are listed for each species. In the fifth column, the percent difference between the average number of fish collected at each site is presented (a positive number means more fish were collected in the highly

Table 12. - Summary statistics for Striped Shiner daily WUA values

\begin{tabular}{|c|c|c|c|c|c|c|c|c|}
\hline Reach & $\begin{array}{c}\text { Juvenile } \\
\text { Mean } \\
\text { WUA }^{*}\end{array}$ & $\begin{array}{c}\text { Adult } \\
\text { Mean } \\
\text { WUA }^{*}\end{array}$ & $\begin{array}{c}\text { Juvenile } \\
\text { Standard } \\
\text { Deviation* }\end{array}$ & $\begin{array}{c}\text { Adult } \\
\text { Standard } \\
\text { Deviation* }\end{array}$ & $\begin{array}{c}\text { Juvenile } \\
\text { Maximum } \\
\text { WUA }^{*}\end{array}$ & $\begin{array}{c}\text { Adult } \\
\text { Maximum } \\
\text { WUA }^{*}\end{array}$ & $\begin{array}{c}\text { Juvenile } \\
\text { Minimum } \\
\text { WUA }^{*}\end{array}$ & $\begin{array}{c}\text { Adult } \\
\text { Minimum } \\
\text { WUA }^{*}\end{array}$ \\
\hline $\begin{array}{c}\text { Straight } \\
\text { Trapezoidal }\end{array}$ & 2705 & 282 & 2533 & 396 & 11912 & 2238 & 130 & 8 \\
\hline $\begin{array}{c}\text { Highly } \\
\text { Sinuous }\end{array}$ & 2785 & 972 & 927 & 976 & 4240 & 3096 & 1336 & 176 \\
\hline $\begin{array}{c}\text { Ratio } \\
\text { (S:H) }\end{array}$ & 0.97 & 0.28 & 2.73 & 0.41 & 2.81 & 0.72 & 0.10 & 0.04 \\
\hline
\end{tabular}

* WUA values for the straight trapezoidal reaches and the highly sinuous reach presented in units of $\mathrm{ft}^{2} / 1000 \mathrm{ft}$

Table 13. - Summary statistics for Striped Shiner difference analysis

\begin{tabular}{|c|c|c|c|c|}
\hline Lifestage & Mean Difference & Standard Deviation & Maximum Difference & Minimum Difference \\
\hline Juvenile & 0.17 & 0.49 & 0.92 & -0.67 \\
\hline Adult & 0.68 & 0.15 & 0.96 & 0.18 \\
\hline
\end{tabular}


Table 14. - HMHD and fish collection results for adult lifestage

\begin{tabular}{|c|c|c|c|c|c|c|c|}
\hline Species & HMHD & $\begin{array}{c}\text { Average \# } \\
\text { Collected } \\
\text { Highly } \\
\text { sinuous }\end{array}$ & $\begin{array}{c}\text { Average \# } \\
\text { Collected } \\
\text { Straight } \\
\text { Trapezoidal }\end{array}$ & $\begin{array}{c}\text { Average \# } \\
\text { Collected } \\
\text { Difference } \\
\text { Ratio } \\
\text { (S:H) }\end{array}$ & $\begin{array}{c}\text { Average } \\
\text { Length } \\
\text { Highly } \\
\text { sinuous } \\
\text { (mm) }\end{array}$ & $\begin{array}{c}\text { Average } \\
\text { Length } \\
\text { Straight } \\
\text { Trapezoidal } \\
\text { (mm) }\end{array}$ & $\begin{array}{c}\text { Average } \\
\text { Length } \\
\text { Ratio } \\
\text { (S:H) }\end{array}$ \\
\hline $\begin{array}{c}\text { Bluntnose } \\
\text { Minnow }\end{array}$ & $\mathbf{0 . 5 6}$ & 158 & 103 & $\mathbf{0 . 5 3}$ & 57 & 45 & 0.79 \\
\hline $\begin{array}{c}\text { Central } \\
\text { Stoneroller }\end{array}$ & $\mathbf{0 . 1 5}$ & 56 & 45 & $\mathbf{0 . 2 0}$ & 66 & 57 & 0.86 \\
\hline $\begin{array}{c}\text { Creek } \\
\text { Chub }\end{array}$ & $\mathbf{0 . 7 7}$ & 39 & 44 & $-\mathbf{0 . 1 3}$ & 98 & 63 & 0.64 \\
\hline $\begin{array}{c}\text { Greenside } \\
\text { Darter }\end{array}$ & $-\mathbf{0 . 2 6}$ & 4 & 1 & $\mathbf{0 . 7 5}$ & 71 & 60 & 0.85 \\
\hline $\begin{array}{c}\text { Longear } \\
\text { Sunfish }\end{array}$ & $\mathbf{0 . 7 8}$ & 9 & 1 & $\mathbf{0 . 8 9}$ & 89 & 71 & 0.80 \\
\hline $\begin{array}{c}\text { Striped } \\
\text { Shiner }\end{array}$ & $\mathbf{0 . 6 8}$ & 30 & 3 & $\mathbf{0 . 9 0}$ & 100 & 70 & 0.70 \\
\hline
\end{tabular}

sinuous reach, and a negative number means more fish were collected in the straight trapezoidal reach). Using the Bluntnose Minnow as an example, the HMHD of 56 indicates that historical habitat conditions were 56 percent better in the highly sinuous reach over the period of record, and there were on average 53 percent more Bluntnose Minnows collected in the highly sinuous reach during this study (conducted over a period of approximately 6 months). Results for four of the species analyzed (Bluntnose Minnow, Central Stoneroller, Longear Sunfish, and Striped Shiner) show a similar relationship.

The HMHD of 77 for the Creek Chub adult indicates that historical habitat conditions were 77 percent better in the highly sinuous reach. Yet there were 13 percent more Creek Chubs collected in the straight trape- zoidal reach. However, the fish collection length data (columns 6 and 7 ) shows that the Creek Chubs collected in the straight trapezoidal reach were on average only 64 percent as large as the Creek Chubs collected in the highly sinuous reach. This could indicate that individuals in the straight trapezoidal reach were juveniles, and therefore the adult WUA data would not apply to them. The Greenside Darter results are also conflicting. The HMHD of negative 26 suggests that historical habitat conditions were 26 percent better in the straight trapezoidal reach for adult Greenside Darters. Yet there were 75 percent more Greenside Darters collected in the highly sinuous reach. This could be due to the use of a general habitat suitability curve rather than a local one for this species, or to the problems associated with the collection of benthic fishes. 


\section{CONCLUSIONS}

Our fish collection and habitat modeling results indicate that channel maintenance has a quantifiable effect on the fisheries in agricultural streams. Differences in physical habitat between the two study reaches were observed for all species analyzed. Therefore, in the midwest, where watersheds are dominated by agricultural use, the predictive capabilities provided by the set of analyses developed here could be beneficial to the consideration of fisheries issues in future stream management and naturalization projects.

Further, the results of the analyses of the PHABSIM predictions indicate that the model can be applied to provide a quantitative assessment of observed physical habitat conditions in agricultural streams. The results of the comparisons of PHABSIM data to fish collection data support the notion that physical habitat can be quantified to some extent and linked to population for a number of midwestern fish species in agricultural streams. Many midwestern fish species are relatively long-lived, and therefore, where physical habitat is the primary limiting factor, fish populations can integrate habitat conditions over long periods of time. It is reasonable to assume then that temporal habitat dynamics can be used as a metric to evaluate potential relative differences in fish populations in midwestern stream reaches that are managed differently. Therefore, the results of the difference analysis (HMHD) presented here could be used as metrics to assess the potential effects of different stream channel maintenance activities on the fish populations in a stream. These metrics could also be used in speciesdirected management efforts to compare the sensitivity of different species of fish to channel management alternatives. Despite the well-documented inability of PHABSIM to accurately predict changes in fish populations at a site under varying flow conditions, our research suggests that PHABSIM can be applied to predict relative differences in fish populations between sites with varying geomorphic features exposed to the same flow conditions.

\section{ACKNOWLEDGEMENTS}

Support for research included in this paper was received from the U. S. Environmental Protection Agency Science to Achieve Results (STAR) research program under the Water and Watersheds Program (EPA R825306-010 and R82-7148-010) and the Climate Change Vulnerability Assessment Program and Regional Impact of Climate Change Program. Support was also provided by the University of Illinois, Critical Research Initiative Program, a Center for Analysis, Assessment, and Mitigation of Regional Impacts from Climate Change.

Support for the preparation and presentation of this paper was provided by the Farrand Conference Presentation Fellowship from the De- 
partment of Landscape Architecture and Environmental Planning at the University of California, Berkeley. Travel support was provided by CH2M Hill.

\section{REFERENCES}

Allan, J.D. 1995. Stream Ecology : Structure and Function of Running Waters. Chapman and Hall. New York. 388 pages.

Armour, C. and J. Taylor. 1991. Evaluation of the instream flow incremental methodology by U.S. Fish and Wildlife Service field users. Fisheries 16(5) : 36-43.

Bovee, K.D. 1982. A guide to stream habitat analysis using the instream flow incremental methodology. Instream flow information paper, 12. U.S. Fish and Wildlife Service, FWS/OBS-82/26.

Bovee, K.D. 1996. Data Collection Procedures for the Physical Habitat Simulation System. U.S. Fish and Wildlife Service. 159 pages.

Bowlby, J.N. and J.C. Roff. 1986. Trout biomass and habitat relationships in southern Ontario streams. Transactions of the American Fisheries Society $115:$ 503-514.

Durham, L. 1997. The Embarras River. In Biological Report 19, Illinois Department of Natural Resources.

Ettinger, W.H. 1989. An intensive survey of the Embarras River basin, 1987. Illinois Environmental Protection Agency Division of Water Pollution Control, Springfield.
Forbes, S.A. and R.E. Richardson. 1908. The Fishes of Illinois. Illinois State Laboratory of Natural History, Bloomington.

Gore, J.A. and J.M. Nestler. 1988. Instream flow studies in perspective. Regulated Rivers : Research and Management 2 : 93-101.

Mathur, D., W.H. Bason, E.J. Purdy, and C.A. Silver. 1985. A critique of the instream flow incremental methodology. Canadian Journal of Fisheries and Aquatic Science 42 : 825-831.

Reiser, D.W., T.A. Wesche, and C. Estes. 1989. Status of instream flow legislation and practices in North America. Fisheries 14(2) : 22-29.

Scott, D. and C.S. Shrivell. 1987. A critique of the instream flow incremental methodology with observations on flow determination in New Zealand. in Kemper, B. and J.F. Craig [eds.] Regulated Streams: Advances in Ecology, Plenium Press, New York, 27-43.

Smith, P.W. 1968. An assessment of changes of the fish fauna of two Illinois rivers and its bearing on their future. Transactions of the Illinois Academy of Science 61(1) : 31-45.

TerHaar, M.J. and E.E. Herricks. 1989. Management and development of aquatic habitat in agricultural drainage systems. Research Report 212 for the University of Illinois Water Resources Center. 145 pp.

Tompkins, M.R. 1998. Analysis of the fisheries of maintained streams using the PHABSIM model and a habitatdriven population model. MS Thesis. University of Illinois, Urbana, 129 pp. 